Hasil Penelitian

\title{
PERUBAHAN PARADIGMA PENDIDIKAN ISLAMz APLIKASI ICT dalam proses pembelajaran paI di sekolaH
}

\author{
Alhmad Lainuri \\ Program Pascasarjana \\ Universitas Islam Negeri Raden Fatah Palembang \\ E-mail:ahmadzainuri_uin@radenfatah.ac.id
}

\begin{abstract}
The use of ICT as a medium of learning and teaching needed to realize the effectiveness and optimization of learning. But be aware that regardless of the medium used learning principles are upheld. It must be recognized that there are still many teachers who "technology illiterate" and must be improved further educational qualifications and professionalism. And that is also the problem is the low level of use of ICT in schools (digital divide) whereas ICT can support the optimization of the school, because of the potential of ICT is quite large. Application of ICT in learning PAI, if carried out by PAI teacher, it will have a positive impact on the interest of students towards subjects PAI in school. So that students in the following subjects PAI is not forced, but self-consciousness. In addition, if the PAI learning in the classroom, teachers use ICT, this will spread the "virus positive" on the teachers of other subjects, so they do the same thing
\end{abstract}

Keywords: Paradigm, ICT Applications and Learning PAI

\footnotetext{
Abstrak

Pemanfaatan ICT sebagai media belajar dan mengajar diperlukan untuk mewujudkan efektifitas dan optimasi pembelajaran. Namun perlu disadari bahwa apapun media yang digunakan prinsip pembelajaran tetap dipegang teguh. Memang harus diakui bahwa saat ini masih banyak guru yang "gagap teknologi" serta harus ditingkatkan lagi kualifikasi pendidikan dan profesionalismenya. Dan yang juga menjadi masalah adalah rendahnya tingkat pemanfaatan ICT di sekolah (digital divide) padahal ICT dapat menunjang optimalisasi sekolah, karena potensi ICT cukup besar. Aplikasi ICT dalam pembelajaran PAI, apabila dilakukan oleh guru PAI, maka akan berdampak positif pada ketertarikan peserta didik terhadap mata pelajaran PAI di sekolah. Sehingga peserta didik dalam mengikuti mata pelajaran PAI tidak terpaksa, melainkan kesadaran diri sendiri. Selain itu, apabila dalam pembelajaran PAI di kelas, guru menggunakan ICT, hal
}

ini akan menyebarkan "virus positif" pada guru mata pelajaran lain, sehingga mereka melakukan hal yang sama.

Kata kunci: Paradigma, Aplikasi ICT, dan Pembelajaran PAI

Menurut M. Sirozi (Sirozi, 2013: 123) mengungkapkan bahwa istilah Information and Communications Technology (ICT) atau Teknologi Informasi dan Komunikasi (TIK) adalah istilah yang relatif baru dalam wacana komunikasi. Dalam kamus Wikipedia, istilah ICT mulai digunakan oleh para peneliti akademik pada tahun 1980-an dan menjadi populer sejak digunakan oleh Dennis Stevenson pada tahun 1997 dalam laporannya kepada pemerintah Inggris tentang perkembangan pendidikan. Istilah ICT semakin dikenal luas setelah digunakan dalam laporan tentang revisi Kurikulum Nasional untuk Inggris, Wales, dan Irlandia Utara pada tahun 2000.

Pengertian ICT terus berkembang mengikuti perubahan yang terjadi pada teknologi dan aplikasinya dalam berbagai konteks dan kebutuhan komunikasi. Saat ini, menurut Wikipedia (2016), istilah ICT digunakan untuk menjelaskan konvergensi antara teknologi audio-visual dan jaringan telepon dengan jaringan komputer melalui kabel tunggal (a single cabling) atau sistem jaringan (link system). Menurut rumusan United Nation Development Programme (UNDP), ICT adalah "seperangkat sumber daya dan peralatan teknologi yang digunakan untuk mengkomunikasikan, menciptakan, mendiseminasi, menyimpan, dan mengelola informasi”. Peralatan teknologi dimaksud antara lain; komputer, internet, teknologi penyiaran (radio dan televisi), dan telepon. 


\section{Hasil Penelitian}

Sarana ICT membuat berbagai aktivitas komunikasi menjadi lebih efektif dan efisien. Aplikasi ICT dalam berbagai konteks dan kebutuhan komunikasi dapat mempercepat proses dan menghemat waktu, biaya, serta tenaga. Misalnya, aplikasi ICT dapat meminialisir, bahkan mengeliminir biaya telepon dan intensitas penggunaan Alat Tulis Kantor (ATK).

Aktivitas kependidikan pada dasarnya adalah aktivitas komunikasi multi dimensi dan multi media yang melibatkan berbagai sumber belajar, baik yang tertulis maupun tidak tertulis, dan juga melibatkan banyak aktor, seperti tenaga pendidik, tenaga kependidikan, peserta didik, dan para pemangku kepentingan pendidikan, terutama para orang tua atau wali, para lulusan, para pengguna lulusan, tokoh agama (toga), tokoh masyarakat (tomas), tokoh pendidikan (topen), dan tokoh pemerintahan (topem). Efektifitas semua dimensi komunikasi yang terjadi dalam proses pendidikan sangat ditentukan oleh aktor yang terlibat beserta sumber dan media komunikasi yang diunakan.

Lebih jauh, M. Sirozi (Sirozi, 2013: 124) mengtakan dengan dukungan ICT, proses komunikasi di semua jalur, jenis, dan jenjang pendidikan dapat berjalan lebih efektif dan efisien. Jika diintegrasikan dalam sistem penyelenggaraan pendidikan, ICT dapat menjadi instrumen yang sangat efektif, efisien, kreatif, produktif, dan menyenangkan. Sarana ICT dapat berperan sebagai instrumen utama bagi para pendidik dan peserta didik dalam mencari (searching), menghimpun (classifying), menghubungkan (connecting), menginterpretasi (interpreting), dan menyajikan (presenting) informasi secara cepat dan menarik, untuk ditransformasikan menjadi ilmu pengetahuan yang bermanfaat. Fungsi-fungsinya yang begitu banyak dan perannya yang begitu penting dalam proses pembelajaran membuat ICT menjadi salah satu sarana utama yang harus ada di setiap lembaga pendidikan. Semua lembaga pendidikan perlu difasilitasi dengan sarana.

ICT yang up to date dan relevan dengan berbagai kebutuhan pelayanan pendidikan, baik pada aspek perangkat keras (hardwares) maupun perangkat lunak (softwares).

Era informasi dan pengenalan ICT di dunia pendidikan telah mengubah paradigma pembelajaran. Di era ini, menurut UNESCO, lembaga-lembaga pendidikan tidak hanya dituntut untuk mendorong peserta didik untuk belajar (to learn), tetapi juga dituntut untuk dapat mendorong peserta didik untuk belajar menguasai ilmu (learning to acquire knowledge), mempromosikan aktivitas belajar bertindak (learning to act), belajar hidup bersama (learning to live together), dan belajar untuk kehidupan (learning for life), dengan paradigma belajar sepanjang hayat (life long learnng).

Di tengah arus informasi yang mengalir deras dan semakin muda diakses, lembaga-lembaga pendidikan tidak bisa lagi sekedar menjadi tempat berlangsungnya transmisi informasi dari guru kepada murid dalam periode waktu dan batasan ruang tertentu. Lembaga-lembaga pendidikan dituntut untuk dapat berperan sebagai fasilitator bagi para pendidik dan peserta didik untuk mengembangkan aktivitas pembelajaran yangmobile, dinamis, dan menembus batasan ruang (spaceless), batasan waktu (timeless), dan batasan kenegaraan (borderless).

Dukungan ICT memungkinkan proses pembelajaran terjadi kapanpun dan dimanapun. Dalam konteks ini maka guru tidak lagi menjadi figur sentral dan sekolah tidak lagi menjadi satusatunya lingkungan belajar bagi peserta didik. Guru dan sekolah hanyalah fasilitator dan mediator pembelajaran. Sarana ICT membuat proses pebelajaran bersifat multi dimensi dan multi purposes. Perubahan paradigma pembelajaran beriringan dengan perubahan paradigma tentang literasi (melek huruf). Di era informasi, menurut seorang futurist, Alvin Toffler (1990), orang yang disebut buta huruf bukanlah orang yang tidak bisa membaca dan menulis, tetapi orang yang tidak bisa belajar (learn), tidak bisa mengubah kebiasaan (unlearn), dan tidak bisa belajar kembali (relearn). Toffler agaknya ingin mengingatkan kita bahwa masyarakat yang hidup di era informasi dituntut untuk memiliki tradisi belajar yang kuat, agar para anggotanya mampu menyerap, mengelolah, dan memanfaatkan informasi secara kritis dan selektif.

Masyarakat yang kuat dan unggul di era informasi adalah masyarakat yang menguasai atau mengendalikan informasi, dan masyarakat yang menguasai informasi adalah masyarakat yang menguasai ICT. Jika tidak disertai dengan tradisi 
belajar yang kuat, penguasaan ICT hanya akan memberikan kesenangan, tidak memberikan ilmu pengetahuan. Dengan tradisi belajar yangg kuat, semua anggota masyarakat memiliki kemauan keras untuk belajar, selalu siap untuk berubah (open minded), dan terus belajar sampai akhir hayat (lifelong education). Pentingnya tradisi belajar yang kuat bagi satu masyarakat diingatkan pula oleh salah satu Presiden Amerika Serikat, Benjamin Franklin, melalui ungkapannya sebagai berikut: "Being ignorant is not so much a shame, as being unwilling to learn" (menjadi orang yang enggan belajar lebih memalukan daripada menjadi orang yang tidak tahu apa-apa).

Tradisi belajar akan menentukan tingkat literasi. Di era informasi, tingkat literasi yag dibutuhkan oleh satu masyarakat untuk dapat berkembang dan bersaing sangat tinggi dan bervariasi. Di era ini, menurut Alvin Toffler (1990), seseorang dituntut untuk melek dalam enam aspek. Pertama, melek fungsional (functional literacy) atau melek visual (visual literacy), yaitu memiliki kemampuan untuk menangkap makna dan mengekspresikan ide-ide melalui berbagai media, termasuk penggunaan images, graphics, video, dan charts. Kedua, melek ilmiah (scientific literacy), mampu memahami aspek-aspek teoritis dan aplikatif dari sains dan matematika. Ketiga, melek teknologi (technological literacy), berkompeten dalam menggunakan berbagai teknologi komunikasi dan informasi. Keempat, melek informasi (information literacy), mampu menggali, mengevaluasi, dan menggunakan informasi secara tepat, termasuk dengan menggunakan TIK. Kelima, melek budaya (cultural literacy), mengapresiasi keragaman budaya. Keenam, kesadaran global (global awareness), memahami bagaimana berbagai bangsa, korporasi, dan komunitas di seluruh dunia terhubung satu sama lain.

Tingkat literasi yang sangat tinggi dan bervariasi menuntut lembaga-lembaga pendidikan untuk tidak hanya berperan sebagai pusat belajar (center for learning), tetapi juga sebagai pusat budaya (center for culture), dan pusat peradaban (center for civilization).

\section{ICT dan Perubahan Paradgima Pembelajaran \\ Keberadaan ICT telah berpengaruh terhadap berbagai aspek kehidupan, termasuk di}

dalamnya aspek pembelajaran. Dalam Proses Belajar Mengajar (PBM) konvensional, guru memiliki keterbatasan dalam mengajar siswa, walaupun masih banyak hal-hal positif juga yang dapat diperoleh darinya. Beberapa keterbatasan itu, diantaranya; interaksi yang terbatas karena umumnya kelas diisi banyak siswa. Selama ini PBM terkendala karena jumlah siswa yang mengikuti kelas mencapai puluhan. Hal ini menjadikan PBM tidak optimal, karena data dan informasi yang tersampaikan kepada siswa tidak maksimal.

Dalam hal ini, beberapa kasus patut diperhatikan. adalah adanya beberapa siswa yang "lambat". Siswa yang lambat bukan berarti ia bodoh, bisa saja ia cerdas tetapi hanya sedikit lambat dalam menerima pengarahan. Di sinilah komputer memahami anak-anak yang lambat dalam belajar, karena gaya belajar hanyalah permasalahan teknis, Dengan menambahkan infrastruktur berupa personal computer $(\mathrm{PC}) /$ komputer, siswa akan mampu mengaktifkan semua indera dan sensitifitasnya melalui melihat, mendengar, dan membaca.

Pemanfaatan ICT sebagai media belajar dan mengajar diperlukan untuk mewujudkan efektifitas dan optimasi pembelajaran. Namun perlu disadari bahwa apapun media yang digunakan prinsip pembelajaran tetap dipegang teguh. Pada saat berbicara mengenai e-Learning atau pendayagunaan media elektronik untuk efektifitas, efisiensi dan kemenarikan pembelajaran hanya berfokus pada kata "e" dan melupakan "learning"nya itu sendiri.

Banyak sekolah yang berlomba-lomba melengkapi sekolahnya dengan fasilitas ICT, tapi pemanfaatannya tidak sesuai dengan kebutuhan. Atau banyak media elektronik yang bisa dimanfaatkan untuk pembelajaran tapi belum dioptimalkan. Keberadaan LCD Projector plus satu laptop dalam satu kelas tidak akan membawa perubahan yang berarti jika hanya digunakan oleh guru untuk menjelaskan pelajaran.

Tapi akan jauh membawa perubahan yang berarti jika siswa diberi kesempatan untuk memanfaatkan teknologi tersebut untuk mengungkapkan ide dan pengetahuannya kepada teman-temannya yang lain Ketika teknologi tersebut hanya dimanfaatkan oleh guru untuk 


\section{Haril Penelitian}

mengajar, maka siswa hanya akan memperoleh pengetahuan tentang apa yang diajarkan dan sedikit gambar atau ilustrasi yang lebih menarik dan konkrit, itupun jika slide presentasi yang dibuatnya baik. Tapi, ketika dimanfaatkan siswa untuk mempresentasikan ide dan pengetahuannya kepada kawan-kawannya yang lain, maka siswa lain akan memperoleh pengetahuan, dan siswa yang berkesempatan menggunakan teknologi tersebut secara tidak langsung mengasah atau meningkatkan ICT literasi mereka dan kemampuan berpikir kritis, problem solving dan lainnya.

Bila kita baca kurikulum 2013, misalnya, ICT memegang peranan yang sangat penting dalam pelaksanaan pembelajaran. Pada kurikulum 2013 dijelaskan bahwa pembelajaran menerapkan prinsip siapa saja adalah guru, siapa saja adalah siswa dan di mana saja adalah kelas. Oleh karena itu, pemanfaatan ICT diperlukan dalam rangkan efektivitas dan efisiensi pembelajaran. Artinya, tidak menutup kemungkinan di tahun-tahun yang akan datang, materi, tugas dan ditransfer melalui ICT.

Perkembangan ICT tentunya menjadi potensi yang sangat besar untuk meningkatkan kualitas pembelajaran. Karena teknologi informasi menyimpan informasi tentang segala hal yang tak terbatas, maka hal ini dapat dimanfaatkan untuk kepentingan pengembangan pembelajaran yang tidak lagi dibatasi oleh ruang dan waktu. Tentunya hal tersebut akan menjadi tantangan besar bagi guru karena dituntut untuk mengerti, memahami, mengoperasikan, dan mengeksplor ICT dengan baik sehingga dapat diaplikasikan dalam pembelajaran.

Di samping itu, guru harus berpikir lebih kreatif, inovatif, dan berwawasan luas sehingga dapat meningkatkan kualitas pembelajaran. ICT dalam pembelajaran dapat menjadi dua peran, yaitu: (1) sebagai media presentasi pembelajaran, misalnya, berbentuk slide power point dan animasi dengan program flash; (2) sebagai media pembelajaran mandiri atau e-learning, misalnya, peserta didik diberikan tugas untuk membaca atau mencari sumber dari internet, mengirimkan jawaban tugas,bahkan mencoba dan melakukan materi pembelajaran.

Melalui e-learning, belajar tidak lagi dibatasi oleh ruang dan waktu. Belajar dapat dilakukan kapan saja dan dimana saja. Hal ini mendorong peserta didik untuk melakukan analisis dan sintesis pengetahuan, menggali, mengolah dan memanfaatkan informasi, menghasilkan tulisan, informasi dan pengetahuan sendiri. Peserta didik dirangsang untuk melakukan eksplorasi ilmu pengetahuan. Fasilitas yang dapat dimanfaatkan oleh peserta didik untuk belajar melalui e-learning, diantaranya; E-Book, E-Library, interaksi dengan pakar, email, mailling list, News Group, dan lainlain. Sedangkan manfaat penggunaan ICT dalam rangka mendukung pelaksanaan pembelajaran adalah: (1) meningkatkan kualitas pembelajaran; (2) memperluas akses terhadap pendidikan dan pembelajaran; (3) membantu memvisualisasikan ide-ide abstrak; (4) mempermudah pemahaman materi yang sedang dipelajari; (5) menampilkan materi pembelajaran menjadi lebih menarik; dan 6) memungkinkan terjadinya interaksi antara pembelajaran dengan materi yang sedang dipelajari. Jika memperhatikan manfaat dari penggunaan ICT ini, tentunya penggunaan ICT dalam pembelajaran maupun lingkungan sekolah tidak dapat dihindari. Sekolah harus senantiasa berupaya untuk memenuhi kebutuhan terhadap fasilitas ICT ini.

Menurut Munir (Munir, 2008:50), secara khusus, tujuan mempelajari ICT adalah; 1). menyadarkan kita akan potensi perkembangan teknologi informasi dan komunikasi yang terus berubah, sehingga termotivasi untuk mengevaluasi dan mempelajari teknologi ini sebagai dasar untuk belajar sepanjang hayat; 2). Memotivasi kemampuan kita agar bisa beradaptasi dan mengantisipasi perkembangan TIK, sehingga bisa melaksanakan dan menjalani aktifitas kehidupan sehari hari secara mandiri dan lebih percaya diri; 3). Mengembangkan kompetensi kita dalam menggunakan TIK untuk mendukung kegiatan belajar, bekerja, dan berbagai aktifitas dalam kehidupan sehari hari; 4). Mengembangkan kemampuan belajar berbasis TIK, sehingga proses pembelajaran dapat lebih optimal, menarik, dan mendorong kita lebih terampil dalam berkomunikasi, terampil mengorganisasi informasi, dan terbiasa bekerjasama; dan 5). Mengembangkan kemampuan belajar mandiri, berinisiatif, inovatif, kreatif, dan bertanggung jawab dalam penggunaan teknologi informasi dan komunikasi untuk pembelajaran, bekerja, dan pemecahan masalah sehari hari. 


\section{Hagil Penelition}

Namun tak dapat dipungkiri bahwa saat ini masih banyak guru yang "gagap teknologi" serta harus ditingkatkan lagi kualifikasi pendidikan dan profesionalismenya. Dan yang juga menjadi masalah adalah rendahnya tingkat pemanfaatan ICT di sekolah (digital divide) padahal ICT dapat menunjang optimalisasi sekolah, karena potensi ICT cukup besar, diantaranya (1)Memperluas kesempatan belajar, (2) Meningkatkan efisiensi, (3) Meningkatkan kualitas belajar, (4) Meningkatkan kualitas mengajar, (5) Memfasilitasi pembentukan keterampilan, (6) Mendorong belajar sepanjang hayat berkelanjutan, (7) Meningkatkan perencanaan kebijakan dan manajemen, (8) Mengurangi kesenjangan digital (Lestari Umi, 2016).

Salah satu aplikasi ICT adalah $e$ Educationyang terus bergulir bagai bola salju yang menggelinding dengan cepat dan semakin besar. Untuk menyikapi hal tersebut, Departemen Pendidikan Jerman, Perancis dan Inggris telah menyusun rencana induk strategis uintuk memanfaatkan ICT dalam pembangunan $e$ Education. Bahkan di Finlandia, pendidikan, pelatihan dan penelitian pada masyarakat informasi telah dicanangkan menjadi strategi nasional. Sedangkan Italia telah membangun infrastruktur $e$ Education dengan membangun lebih dari 15.000 sambungan Internet sekolah (Sutedjo, 2002:6). Dalam pendidikan tinggi, sudah dilancarkan Visi Kampus Elektronik atau Electronic Campus dimana setiap bagian, unit, fakultas di lingkungan kampus dihubungkan satu sama lainnya secara elektronik.

Bahkan di Indonesia, terutama di Riau saat ini, menurut berita terbaru Tribun Pekanbaru, telah diaplikasikan program Schoolnet yang merupakan sebuah Jejaring Pendidikan Nasional (Jardiknas) yang terselenggara atas kerjasama Kementerian Pendidikan Nasional melalui Pusat Teknologi Komunikasi dan Informasi Pendidikan (Pustekkom) dengan PT. Telkom Tbk. Program ini menyediakan fasilitas modem dan layanan Internet gratis ke sejumlah sekolah di seluruh kabupaten/kota di Riau. Selain program Schoolnet ini Kemendiknas juga menyediakan program lainnya, yaitu; Televisi Edukasi (TvE) dan Buku Standar Elektronik (BSE) (Tribun Pekanbaru, 30 Agustus 2009:3).

Untuk masuk ke internet seseorang harus menggunakan web brouser. Dewasa ini web brouser yang paling terkenal adalah Internet
Explorer (IE), Netscape, Opera7, Mozilla's Firefox, Mosaic, dan Lynx. Mozilla merupakan yang terbaru dan merupakan yang terbaik menurut versi perusahan Amerika (Khan, 2006:34). Masyarakat penggunaan internet tergantung pada jenisnya, misalnya, Electronic Mail, News Group, World Wide Web (WWW), Internet Voice, dan Internet Relay Chat (IRC).

Semua aplikasi di atas dapat digunakan untuk tujuan pendidikan. Penggunaan ICT dalam pembelajaran dapat dilakukan untuk memberikan tutorial, latihan, pencarian, dan aplikasi riil atau praktek, yang berperan dalam membantu meningkatkan minat belajar. Keadaan ini secara tidak langsung akan memudahkan proses pembelajaran, dan akhirnya dapat meningkatkan hasil belajar. Dalam kajian Psikologi Kognitif, kemampuan ingatan seseorang terbagi kepada tiga jenis yaitu kemampuan menerima, menyimpan dan memunculkan kembali informasi. Ingatan mempunyai pengaruh yang cukup besar terhadap keberhasilan pembelajaran. Semakin baik kemampuan ingatan seseorang, maka semakin banyak informasi yang mampu dia cerap, semakin banyak informasi yang bisa ia simpan, dan semakin banyak pula informasi yang mampu dia munculkan kembali (Promadi, 2008 :113). Dengan bantuan ICT, kemampuan menerima, menyimpan, dan memunculkan kembali dapat diakselerasi, sehingga lebih efektif dan efisien. Dengan demikian keberhasilan pembelajaran dapat ditingkatkan.

ICT juga dapat meningkatkan komunikasi pembelajaran dalam arti yang lebih luas, mencakup interaksi antara pembelajar dan pengajar dan antara sesama pembelajar. Komunikasi pembelajaran ini bahkan dapat diperluas lagi menjadi interaksi antara pelajar dan program dalam komputer, interaksi face tao face antara pelajar dan pelajar lain berbasis program dalam komputer, dan bahkan interaksi pelajar dan pelajar lain melalui media komputer secara maya atau melalui kelas virtual. Dengan adanya interaksi ICT dalam pendidikan ini, terjadi penglibatan yang aktif antara pengajar dan pembelajar, yang selanjutnya dapat mengakselerasi pembelajaran sehingga lebih efisien.

Dengan demikian integrasi ICT dalam pendidikan memainkan peranan yang besar dan penting dalam meningkatkan kualitas pembelajaran. Bill Gates (1999), dalam bukunya 


\section{Hasil Penelitian}

Business @ The Speed of Thought menyatakan bahwa komputer pribadi dapat mengubah metode pembelajaran tradisional, dimana biasanya pengajar memberi instruksi, berpindah ke pendekatan hands on yang sepenuhnya menggunakan sifat inkuiri yang ada dalam diri pembelajar. Komputer pribadi memungkinkan mereka menjelajahi alam raya guna mencari informasi sesuai kesanggupan dan kemampuan masing-masing. Pengenalan kepada ICT dapat membawa kepada sikap yang positif di kalangan pembelajar. Ini karena ICT menyediakan peluang yang luas dalam aktivitaspembelajaran dibandingkan dengan metode tradisional.

Melalui penggunaan Internet pembelajar boleh menimba ilmu pengetahuan serta contohcontoh yang praktis dan kontekstual serta ril. Kemudahan hypermedia dan multimedia telah memudahkan pendekatan dan metode belajar yang tidak mungkin dapat dilaksanakan sekiranya menggunakan metode tradisional. ICT menyediakan metode tidak hanya dalam model penerimaan ilmu secara satu arah saja, akan tetapi juga dengan memberi penekanan kepada penciptaan dan penjelajahan atau penerokaan ilmu secara aktif, inovatif, kreatif, efektif dan bahkan menyenangkan. Konsep pembelajaran PAIKEM dapat diciptakan dengan penggunaan multimedia dengan pengintegrasian ICT ke dalam pembelajaran.

Dalam konteks pembelajaran, ICT digunakan sebagai tutor dan alat demonstrasi. Untuk mencapai tujuan menciptakan masyarakat modern mewujudkan masyarakat yang informatif, maka inisiatif untuk mengintegrasikan penggunaan ICT dan multimedia dalam pembelajaran adalah perlu. Misalnya, ICT dapat membantu mengatasi kelemahan pendidikan sains yang diajar secara tradisional serta dapat mempertingkatkan penglibatan pengajar dan pelajar dalam penggunaan komputer secara lebih produktif. Pengajar harus mampu mengintegrasikan kemahiran teknologi dan peluang pembelajaran konstruktivis untuk melihat keefektifan penggunaan teknologi. Meskipun demikian, integrasi ICT dalam pembelajaran memerlukan kemahiran khusus dan komitmen pengajar secara terfokus.

Beberapa karakteristik unik yang dimiliki internet, yaitu akses universal, kaya akan multimedia resources, media publishing, dan media interaktif (Khurshid Ahmad, dkk, 1985:4).
Komputer memiliki kemampuan menyimpan, mengorganisir, mengubah, mengirim dan menyajikan sejumlah besar data dalam kecepatan yang tinggi, baik data berbentuk angka, teks, grafik, suara, dan bahkan mungkin ke depan data berbentuk sentuhan dan bau. Fasilitas ICT yang mampu menyimpan, mengatur dan menyajikan kembali sejumlah besar informasi memberikan sumber belajar berbasis pengetahuan yang sangat kaya kepada pelajar.

Dengan menggunakan media internet dan CD/DVD, pelajar dapat mengakses informasi yang tidak tersedia di dalam kelas atau perpustakaan sekolah, seperti gambar-gambar artifak dari musem manapun di seluruh dunia, koran, majalah, rekaman pidato, atau film dan sebagainya. Informasi multimedia mencakup topik-topik sejak zaman kuno. Dokumen-dokumen dan database yang berada di wilayah-wilayah terpencil, dapat diperoleh melalui jaringan komputer internasional. Dan komunikasi elektronik dapat dilaksanakan antara dua pihak yang saling memerlukan di seantero dunia, bahkan dapat melakukan pembicaraan dengan para profesor melalui chatroom atau ruang mengobrol (Loveless, 2003:7).

\section{Aplikasi ICT dalam Pembelajaran PAI}

Bila diperhatikan penggunaan ICT dalam proses pembelajaran, seolah-olah, peran seorang guru menjadi tumpang-tindih atau redundant, dimana fungsi pengajaran mereka digantikan oleh mesin, sedangkan guru hanya rileks. Akan tetapi, peran mereka sebenarnya menjadi semakin penting, karena peran tersebut akan berbeda-beda sesuai tahap-tahap pembelajaran; sebelum pelajaran dimulai, selama proses pembelajaran, dan setelah pelajaran berakhir.

Sebelum pelajaran dimulai, guru adalah sebagai perancang, mengecek sumber belajar dan perlengkapan IT, melakukan peninjauan awal (preview) terhadap bahan pelajaran, dan mengantisipsi berbagai kemungkinan permasalah yang akan timbul selama proses pembelajaran. Selama proses pembelajaran, guru memonitor aktifitas instruksional, serta memfasilitasi berbagai variasi belajar yang memproses pengalaman belajar siswa. Selesai pembelajaran, guru perlu mereview materi dan pengalaman belajar siswa berbasis ICT, dan mempastikan adanya keterkaitan yang jelas 


\section{Haril Penelitian}

materi dan pengalaman belajar dengan kurikulum dan prosedur penilaian (Michael D. Williams, 2000:15).

Integrasi ICT dalam pendidikan mengakomodir teori belajar Behavioris yang dipopulerkan oleh BF. Skinner, dimana pelajar akan mengembangkan bentuk responnya secara bertahap terhadap stimulus ketika respon mereka diikuti oleh reinforcement tertentu. Tugas yang diberikan melalui komputer sebagai stimulus direspon oleh siswa dengan memberikan jawaban, kemudian diberi penguatan oleh program, umpamanya dengan memunculkan wajah yang tersenyum, apabila jawaban mereka benar. Dengan cara ini pelajar akan mengembangkan pengetahuan dan ketrampilannya. Tugas-tugas merespon dan reinforcement ini diambil alih oleh mesin komputer dan programnya.

Integrasi ICT dalam pendidikan juga mengakomodir teori belajar Cognitivism, dimana dengan bantuan ICT siswa melakukan proses bagaimana informasi diterima (teks, suara, gambar, grafis, animasi atau multimedia interaktif), diproses dan disimpan dalam komponen memori, baik jangka pendek maupun jangka panjang. Cara kerja otak siswa dalam pembelajaran berbasis ICT diarahkan mengikuti cara kerja komputer, yang oleh Melvin L. Silbermann (1996) dianalogikan tidak jauh berbeda, karena keduanya tidak hanya sekedar menerima informasi, tapi mengolahnya. Sebagaimana komputer, otak perlu di'hidup"kan terlebih dahulu baru dia akan menerima input data. Ketika kegiatan belajar sifatnya pasif, itu berarti otak tidak sedang hidup atau berada pada posisi "OFF" dan perlu dihidupkan terlebih dahulu. Siswa dibimbing untuk mengterpretasikan data agar dipahami dan kemudian disimpan agar bisa diminta kembali bila diperlukan.

Dalam konteks inilah, sebenarnya banyak guru PAI sudah menguasai ICT, tetapi masih sekadar dimanfaatkan untuk mengetik. Padahal manfaat ICT dalam pembelajaran dapat dimanfaatkan lebih dari itu. Menurut Hery Nugroho (2016) bentuk pemanfaatan ICT dalam pembelajaran PAI adalah; pertama: penggunaan program powerpoint dalam proses pembelajaran PAI di kelas. Melalui proram tersebut, guru tinggal menulis poin-poin penting materi yang akan disampaikan. Agar lebih menarik, guru bisa juga menggunakan program macromedia flash.Tidak hanya tulisan yang dapat disampaikan ke peserta didik, tetapi juga dapat menampilkan suara atau video yang berkaitan dengan materi tersebut. Misalnya, dalam materi pembelajaran tentang Iman Kepada Hari Akhir. Melalui program ini, peserta didik tidak hanya mendapatkan pengetahuan materi tersebut, tetapi juga dapat ditampilkan ilustrasi tentang kiamat sughra dan kubra. Melaui pembelajaran seperti itu, ternyata peserta didik lebih mudah memahami dan tertarik.

Kedua, menggunakan $e$-mail untuk mengumpulkan tugas dari peserta didik. Sekarang ini yang biasa dilakukan guru PAI kepada peserta didik dalam mengumpulkan tugas melalui buku atau kertas. Bisa dibayangkan bagaimana kalau guru PAI mengajar di 18 kelas. Masing-masing kelas berjumlah 40 siswa. Berarti ada 720 buku tugas atau makalah yang menumpuk di bawah atau atas meja guru.Pengumpulan tugas melalui $e$ mail justru sekaligus mendidik peserta didik untuk mengurangi global warming. Kita tahu bahwa bahan baku kertas berasal dari kayu. Artinya, semakin banyak peserta didik menggunakan kertas, maka bertambah banyak penebangan kayu untuk bahan baku kertas. Tidak salah kalau sekarang hutan di Indonesia semakin berkurang. Karenanya, peserta didik perlu dilatih untuk mencegah global warming sekaligus menyelamatkan dunia dengan cara meminimalisasi penggunaan kertas.

Ketiga, menggunakan mailing list untuk diskusi kelas yang diajarkan. Melalui mailing list guru PAI dapat membuat grup atau kelompok sendiri, bisa berupa satu kelas atau satu sekolah untuk berkomunikasi. Di sini guru PAI menginformasikan materi pembelajaran yang akan disampaikan pada pertemuan ke depan via mailing list. Sedangkan seluruh anggota grup akan mengetahuinya dalam waktu bersamaan. Saat itu juga peserta didik dapat men-downloadmateri tersebut dari rumah atau di mana pun tempatnya asalkan ada jaringan internet.Selain itu, melalui mailing list guru dapat membuka ruang diskusi dengan peserta didik. Selama ini kesempatan bertanya peserta didik masih terbatas di ruang kelas. Melalui program tersebut, guru dapat membantu masalah yang dihadapi peserta didik kapan pun dan di mana pun mereka berada. 


\section{Hasil Penelitian}

Keempat, menggunakan web blog untuk pembelajaran di dalam atau di luar kelas. Ketika disebut web blog, banyak guru bertanya-tanya: mahalkah biayanya? Memang, untukwebsite yang komersial, pengguna (user) harus membayar sesuai tarif. Tetapi untuk web blog, pengguna tidak harus membayar alias gratis. Dibanding fasilitas ICT, web blog lebih sempurna. Di antara kelebihannya, guru dapat menampilkan semua karya atau hasil pemikiran yang dimiliki.Web blog dapat digambarkan seperti surat kabar pribadi guru. Surat kabar tersebut mau diisi apa tergantung pada guru. Hubungannya dengan pembelajaran, guru PAI dapat mengunggah (upload) semua materi pembelajaran PAI ke website. Melalui media ini peserta didik dapat belajar tanpa dibatasi ruang kelas. Tidak hanya materi pembelajaran, tetapi juga latihan soal, hasil ujian/ulangan atau materi lain yang berhubungan dengan materi PAI.Khusus hasil ujian, selama ini peserta didik atau orang tua hanya mengetahui hasil ujian miliknya sendiri, sedangkan hasil ujian temannya belum tentu tahu. Melalui web blog, peserta didik dapat melihat hasil ujian secara keseluruhan. Sehingga, apabila ada kekeliruan, peserta didik atau orang tua dapat konfirmasi pada guru tentang mata pelajaran tersebut.

Dari keempat penggunaan ICT dalam pembelajaran, apabila dilakukan oleh guru PAI, maka akan berdampak positif pada ketertarikan peserta didik terhadap mata pelajaran PAI di sekolah. Sehingga peserta didik dalam mengikuti mata pelajaran PAI tidak terpaksa, melainkan kesadaran diri sendiri. Selain itu, apabila dalam pembelajaran PAI di kelas, guru menggunakan ICT, hal ini akan menyebarkan "virus positif" pada guru mata pelajaran lain, sehingga mereka melakukan hal yang sama. Guru PAI saja--yang sering kali dianggap ketinggalan dibanding guru mata pelajaran lain--dalam pembelajaran di kelas menggunakan ICT. Mengapa mata pelajaran yang lain tidak memanfaatkannya juga? Last but not least. (Tidak ada kata terlambat) untuk melakukan perubahan dalam pembelajaran.

\section{Probematika Penggunaan ICT dalam PAI}

Seperti dikatakan Khairatul Aini (2016) bahwa ICT telah membantu guru dalam proses pembelajaran PAI di sekolah. Namun sebagaimana dijelaskan Promadi (2009) selain ICT dapat membantu guru PAI, terdapat pula berbagai problematika, khususnya berkaitan dengan penerapan e-Education. Problematika dimaksud dapat diuraikan sebagai berikut.

Pertama; belum terbentuknya high trust society, yaitu perubahan budaya belajar dari pola belajar konvensional ke budaya berbasis ICT. Etika pendidikan berbasis internet belum terumuskan dan tersosialisasi, begitu juga tingkat kepercayaan masyarakat yang masih meragukan validitas hasilnya. Perubahan pola pembelajar dari yang cenderung pasif menunggu materi pendidikan kepada pembelajar yang aktif mencari materi pendidikan.

Kedua, sarana dan prasarana belum memadai, sehingga fasilitas yang disediakan masih belum lengkap dan kebanyakan sekolah cuma dilengkapi dengan beberapa projektor LCD saja dan setiap kelas masih belum mempunyai satu LCD projektor. Akibatnya, guru PAI yang sudah memiliki ketrampilan mengintegrasikan ICT dalam pembelajaran, justru tidak mengaplikasikannya dalam proses pembelajaran. Bahkan guru bidang studi TIK sendiri hanya mampu mengajarkan apa yang ada dalam buku teks, tanpa dia sendiri terlibat langsung dalam pengintegrasian TIK dalam pembelajaran. Apalagi guru PAI yang terkadang memang tidak dibekali dengan kemampuan ICT dan fasilitas yang tidak memadai.

Ketiga, minimnya SDM yang memahami dan menguasai dengan baik konsep dan implementasi ICT dalam pendidikan. Sehingga cara pembelajaran PAI mereka masih berbentuk tradisional, yaitu dengan menggunakan papan tulis (hitam ataui putih) dan kapur tulis atau spidol.

Keempat, etika dan moralitas masih belum mendapat tempat yang tepat, sehingga sistem $e$ Education dimanfaatkan oleh pihak-pihak tertentu untuk melakukan pelanggaran etika dan moralitas, seperti menjajakan situs pornografi.

Kelima, masih adanya persepsi yang kurang positif di kalangan para pendidik tentang ICT, seperti phobia komputer yang menganggap ICT sebagai barang mewah dan untuk mengapilkasikannya memerlukan keahlian khusus. Persepsi ini mengakibatkan para pendidik tidak mau menggunakan komputer karena takut akan terjadi kerusakan. Akhirnya mereka tidak mau menggunakan komputer untuk membantu mereka 


\section{Haril Penelitian}

dalam profesinya sebagai tenaga kependidikan, padahal ini merupakan satu kemestian di abad ini.

Dalam rangka memodernisasikan pembelajaran PAI dengan penggunaan ICT, bagaimanapun, para pengajar harus terlebih dahulu menguasai kemahiran penggunaan ICT. Para pembelajar juga harus memanfaatkan peluang untuk memperkaya ketrampilan mereka dengan ICT. Tidak dapat disangkal lagi bahwa integrasi ICT dalam pembelajaran PAI hanya akan efektif jika ketersediaan perangkat dan fasilitas ICT lengkap dan para pengajar memiliki asumsi yang positif dan tidak ada phobia komputer. Para guru PAI diharapkan dapat melakukan proses pembelajaran dengan menggunakan pendekatan ekpositori, inkuiri, dan teori belajar Consctructivism dengan ICT. Penggunaan ICT dalam pembelajaran ekpositori, inkuiri dan constructivism menuntut pengajar lebih berperan. Mereka perlu kreatif dalam pembelajaran untuk menarik minat dan kesiapan belajar para peserta didik.

$$
\text { Sebagai tanggungjawab tenaga }
$$
kependidikan yang profesional, walaupun terdapat halangan di sekolah-sekolah dalam penggunaan ICT, pengajar harus tetap mengajarkan ICT dan menggunakan ICT dalam pembelajaran. Sekurangkurangnya mereka tidak buta ICT. Kalau memang sejak sekarang memiliki impian untuk menjadi tenaga kependidikkan yang professional dan memiliki nilai kompetitif didunia global.

\section{Kesimpulan}

Pada bagian simpulan ini, penulis hanya ingin menegaskan kembali perkembangan ICT sudah menjadi keniscayaan. Pengintegrasian ICT dalam pembelajaran membawa perubahan besar dalam dunia pendidikan, baik pada tataran konsep, teori dan aplikasi. Pendekatan, metode dan teknik pembelajaran baru bernuansa ICT kian berkembang sesuai perkembangan ICT itu sendiri. Software pendidikan berlabel e (e-education, e-learning, $e$ book, e-library) kian menjamur di tataran aplikasi. Pengintegrasian ICT dalam pembelajaran PAI adalah satu kemestian. Konsep edutainment, yang merupakan penggabungan pendidikan dan hiburan, memasuki babak baru dunia pendidikan, termasuk pendidikan Islam.
Belajar ilmu-ilmu keislaman, seperti alQur'an, Shalat, Haji, Iman, Sejarah Islam, Aqidah, dan sebagainya tidak lagi sekedar dipresentasikan secara manual-tradisional. Tetapi secara moderninteraktif menggunakan multimedia dalam berbagai bentuk dan tersedia di berbagai tempat di dunia global, disediakan oleh berbagai sumber dan dapat diakses dengan mudah, cepat, dan murah, dapat digunakan dalam kelas tradisional maupun dalam kelas maya atau virtual.

Kondisi ini akan kian terus berkembang mengikuti kemajuan berpikir dan pelaku pendidikan profesional. Phobia ICT, tidak hanya akan membuat guru PAI akan ketinggalan, bahkan akan tidak memiliki ruang dan kesempatan untuk berkarya dalam bidangnya karena era globalisasi mengutamakan aspek kompetitif guna menjamin mutu pendidikan. Pendidik yang tidak memiliki kompetensi dalam memenangkan percaturan global, akan dengan secara teratur tersisihkan oleh kondisi yang tidak direncanakan. Agar guru PAI bisa eksis di masa depan, diperlukan visi jauh ke depan, dan merancang sejak dini kesiapan dan persiapan apa yang hendak dibawa guna eksis di masa depan. Guru PAI memiliki tugas dan tanggung jawab mempersiapkan anak didik supaya bisa hidup tidak di zamannya.

\section{Daftar Pustaka}

"Teknolgoi Informasi dan Komunikasi", dalam https://id.wikipedia.org/wiki/Teknologi_Info rmasi_Komunikasi, diakses, 19 Agustus 2016, pukul 19.30 WIB

Ananda Setyo G. Anti Kaget Internet. Jakarta: Creative Media. 2006.

Ann Jones, dkk. Personal Computers for Distance Education, The Study Of An Educational Innovation, London. 1999.

Budi Sutedjo Dharma Oetomo. e-Education: Konsep, Teknologi dan Aplikasi Internet Pendidikan. Yogyakarta: Penerbit ANDI. 2002.

Hery Nugroho, "Pembelajaran PAI Berbasis ICT", dalam website: http://herynugrohoyes. wordpress.com /2012/08/11/pembelajaranpai-berbasis-ict/,diakses, 19 Agustus 2016, pukul 19.00 WIB

Khairatul Aini, "Urgensi Penggunaan ICT Bagi Guru PAI", dalam 


\section{Hasil Penelitian}

http://suarakampus.com/?mod=opini\&se=de til\&id=13, diakses, 19 Agustus 2016, pukul 19.30 WIB

Khurshid Ahmad, et al. Computers, Language Learning and Language Teaching, Cambridge: Cambridge University Group Loveless. 1985.

Lestari Umi. “Dampak Teknologi Informasi dan Komunikasi (TIK)Terhadap Aktivitas Pendidikan", dalam http://umilestari67. wordpress.com/ 2011/04/ 03/makalahdampak-teknologi-informasi-dankomunikasi-tik-terhadap-aktivitaspendidikan/diakses, 19 Agustus 2016, pukul 20.30 WIB

M. Sirozi. Konteks dan Kerangka Konseptual Kajian Politik Pendidikan. Palembang: Noerfikri Offset. 2013.

Melvin L Silberman, (1996), Active learning: 101 Strategies To Teach Any Subject, Boston: Allyn and Bacon Posted under
Michael D. William. Integrating Technology Into Teaching and Learning: Concept and Appllication. New York: Prentice Hall. 2002.

Munir. Kurikulum Berbasis Teknologi Informasi dan Komunikasi. Bandung: Alfabeta. 2008.

Promadi. "Integrasi ICT dalam Pendidikan Islam: Suatu Alternatif Pendekatan Pembelajaran Masa Depan".Makalah disampaikan pada Kuliah Umum mengawali Semester Ganjil TA 2009/2010 pada Fakultas Tarbiyah dan Keguruan UIN Sultan Syarif Kasim Riau. Rabu, 2 September 2009, di Gedung PKM UIN SUSKA RIAU

Promadi. Pendekatan Komunikatif dalam Pembelajran Bahasa Arab Melalui Kelas Maya. Pekanbaru: Suska Press. 2008.

Rachel E. Khan. Internet 101, The New Mass Medium for Filipinos. Pasig City: Anvil Publishing, Inc. 2006. 